\title{
Nutritive Value and Intake of Kleberg Blue- stem by Beef Cattle
}

\author{
M.E. PACHECO, R.D. BROWN, AND R.L. BINGHAM
}

\section{Abstract}

Four cuttings of Kleberg bluestem (Dicanthium annulatum) were fed to 15 Santa Gertrudis steers to develop prediction equations for intake based on nutrient analyses of the forage with 4 replications. The $\mathbf{4}$ forages were found to differ in nutrient content $(P<.05)$ and intake $(P<.005)$. DE and DMD of Kleberg bluestem can be accurately predicted by laboratory means; however, prediction of intake of this forage with present analysis is impractical.

In order to adequately and economically supplement cattle on low quality pastures it is important to first ascertain the level of nutrients supplied by forage. Thus the ability to measure nutrients and predict the intake of low quality forage by grazing cattle is critical. Kleberg bluestem (Dichanthium annulatum) is a common forage in the South Texas region. Previous studies (Hertel 1976) have found this forage to be of generally low nutrient content, and to exhibit a wider annual variation in DE than other local grasses. The purpose of this study was to measure the intake of this forage in relation to its nutrient content in order to develop a predictive equation.

\section{Materials and Methods}

Kleberg bluestem was harvested from three different locations in South Texas. A fourth cutting was taken from regrowth in one location. After harvesting, the forages were stored as square bales. The hays were analyzed for IVDMD and found to be different $(P<.05)$ in this aspect of their quality.

Sixteen Santa Gertrudis steers, with an average beginning weight of $204.3 \mathrm{~kg}$, were maintained in a single $29 \times 12 \mathrm{~m}$ pen. A shed at one end housed 16 Calan Electronic Feeding Gates ${ }^{1}$, thus allowing individual feed intake to be measured on each animal. Water was available ad libitum.

During each of 42 -week trials the steers were randomly divided into 4 treatment groups, each group assigned to one hay. The cattle were weighed before and after each trial and the average weight of each individual was used for intake calculations. The hays were chopped to a length of $315 \mathrm{~cm}$ ad libitum. The amount of feed offered was measured daily while orts were collected weekly for the calculation of average daily feed intake per animal. During each trial, a 7-day adjustment period was followed by a 7-day collection period.

During each trial 1 steer in each of the 4 treatment groups was fitted with a fecal collection bag. Feces were collected and weighed, and aliquots were taken daily. Daily collections were combined at the end of the week and frozen until analysis.

At the end of each 14-day trial the animals were maintained on the same hay and supplemented with $.908 \mathrm{~kg}$ of a grain mix to allow for growth and recuperation from the nutritional stress of the low quality forage. After each 10-day supplementation period, the grain was withdrawn, the cattle randomly reassigned to another forage, and the experiment repeated. Due to an animal handling

\footnotetext{
Authors are research assistant, College of Agriculture, associate research scientist and statistician, Caesar Kleberg Wildlife Research Institute, Texas A\&I University, Box 218, Kingsville 78363 .

Manuscript received August 10, 1982
}

'American Calan Inc. Rt. 4, Northwood, NH 03261. problem, one of the forages had 4 steers in only 3 trials.

Samples of the forages offered were taken daily. Proximate (AOAC 1970) and Van Soest (Goering and Van Soest 1970) analyses were made on weekly composite aliquots. Crude protein was determined by a modified, micro-Kjeldahl procedure (Bremner 1965). Gross energy of feed and fecal samples was determined with a Parr bomb calorimeter. Calcium, phosphorus, and nitrates were determined spectrophotometrically on 1 sample of each forage by the Texas A\&M Feed Analysis Lab, College Station. In vitro digestibility determinations were done by the Tilley and Terry two-stage method as modified by Moore and Dunham (1971). In vivo digestibility determinations were performed by procedures outlined by Schneider and Flatt (1975). Density of each of the 4 forages was determined by the plywood box method (Penn State Mimeo. 1978).

For statistical analysis, the intakes of inividual animals on each trial were compared with the nutrient analysis of the 4 hays for that specific trial. Statistical analysis was conducted using the Biomedical Computer Programs Statistical Package (BMDP), P-Series (1977). Multiple stepwise regression (EMDP2R) was used to investigate the relationships between intake (DMI/ bw ${ }^{75}$ ) and the laboratory analyses and digestibility values. The relationship between intake and 13 of the more practically measured variables was also examined using all possible subsets regression (BMDP5R). Statistical analyses were also conducted using DE, TDN, and DMD as dependent variables in order to determine predictive equations for these from the other laboratory determinations.

\section{Results and Discussion}

The overall findings indicate that the nutritive value of this grass was low (Table 1). The results of the Proximate and Van Soest analyses are similar to those of other tropical grasses (Moore and Mott 1973) and to the results of Hertel (1976) of the analyses of 40 samples of Kleberg bluestem.

The digestibilities of all of the components determined on this forage were depressed (Table 2). This was probably a consequence of the high fiber and silica and low protein content of these forages. Tropical grasses tend to be lower in quality and digestibility than temperate grasses of the same maturity (Moore and Mott 1973). Van Soest and Jones (1967) reported a 3\% decrease in digestibility for every $1 \%$ increase in silica content of forages. The nutritive value of the hays also affected intake, as the overall intake of the forages was less than $2.0 \%$ of the body weights of the steers throughout the experiment.

An analysis of variance showed the difference of the DMl $/ \mathrm{bw}{ }^{75} \mathrm{~kg}$ of the 4 hays to be highly significant $(P<.005)$. A multiple stepwise regression analysis regressing $\mathrm{DMI} / \mathrm{bw}^{75} \mathrm{~kg}$ on all 33 laboratory and digestibility variables resulted in the equation, $\mathrm{DMI} / \mathrm{bw}_{\mathrm{kg}}^{75}=.856-$ $.014(\mathrm{DM})+.004(\mathrm{NFE})+.007(\mathrm{HEMI})+.015(\mathrm{CPD})$ with $r^{2}=.38$.

Since in vivo $\mathrm{CPD}$ is an impractical value for routine analysis, an all possible subsets regression analysis was conducted utilizing 13 of the 33 variables. The 13 variables were selected for their ease of determination in the laboratory. The regression analysis yielded the prediction equation, DMI/bw ${ }^{.75}=-.551+.015$ (CP) -.006 (CF) $-.019(\mathrm{NDIASH})+.015(\mathrm{LIG})+.010(\mathrm{SIL}+.022(\mathrm{HEMI})$ 
Table 1. Analyses of 4 cuttings of Kleberg bluestem hay used in a feed intake experiment.

\begin{tabular}{|c|c|c|c|c|c|c|c|c|c|c|c|}
\hline \multirow[b]{2}{*}{ Proximate analyses } & \multirow{2}{*}{$\begin{array}{c}\text { Text } \\
\text { abbreviations }\end{array}$} & \multicolumn{10}{|c|}{ Hays ${ }^{\prime}$} \\
\hline & & $A^{2}$ & S.D. & B & S.D. & C & S.D. & D & S.D. & $\bar{X}$ & S.D. (\%) \\
\hline Dry matter & DM & 89.3 & .23 & 89.3 & .53 & 89.5 & .18 & 88.9 & .47 & 89.3 & .42 \\
\hline Crude protein & $\mathrm{CP}$ & 4.2 & .26 & 3.7 & .31 & 4.0 & .38 & 4.2 & .05 & 4.0 & .34 \\
\hline Ether extract & EE & 2.5 & .11 & 1.4 & .14 & .8 & .07 & 1.1 & .50 & 1.4 & .65 \\
\hline Crude fiber & $\mathrm{CF}$ & 19.8 & .52 & 22.1 & 1.78 & 24.8 & 1.51 & 22.9 & 1.37 & 22.4 & 2.23 \\
\hline Ash & ASH & 12.8 & .11 & 10.7 & .49 & 10.7 & .72 & 9.8 & .23 & 10.9 & 1.13 \\
\hline Nitrogen free extract & NFE & 60.7 & .81 & 62.2 & 2.05 & 59.7 & 2.10 & 62.0 & .99 & 61.2 & 1.92 \\
\hline \multicolumn{12}{|l|}{ Van Soest Analyses (\%) } \\
\hline Neutral detergent fiber & NDF & 70.2 & 1.36 & 74.1 & .64 & 77.5 & .71 & 74.7 & 1.45 & 74.4 & 2.72 \\
\hline Cell contents & $\mathrm{CC}$ & 29.8 & 1.36 & 25.9 & .64 & 22.5 & .71 & 25.3 & 1.45 & 25.6 & 2.71 \\
\hline Acid detergent fiber & ADF & 44.7 & .64 & 49.5 & .48 & 52.0 & .71 & 51.3 & .85 & 49.7 & 2.80 \\
\hline $\begin{array}{l}\text { Neutral detergent } \\
\text { insoluble ash }\end{array}$ & & & & & & & & & & & \\
\hline $\begin{array}{l}\text { insoluble ash } \\
\text { Lignin }\end{array}$ & $\begin{array}{l}\text { NDIASH } \\
\text { LIG }\end{array}$ & $\begin{array}{l}2.0 \\
62\end{array}$ & .40 & 1.4 & .38 & 1.2 & .24 & 1.0 & .57 & 1.4 & .54 \\
\hline $\begin{array}{l}\text { Lignin } \\
\text { Cellulose }\end{array}$ & $\begin{array}{l}\text { LIG } \\
\text { CELL }\end{array}$ & $\begin{array}{r}6.2 \\
30.9\end{array}$ & $\begin{array}{l}.21 \\
.52\end{array}$ & $\begin{array}{r}7.5 \\
34.6\end{array}$ & $\begin{array}{l}.21 \\
.66\end{array}$ & $\begin{array}{r}7.6 \\
37.9\end{array}$ & $\begin{array}{l}.36 \\
.5 !\end{array}$ & $\begin{array}{l}10.3 \\
36.1\end{array}$ & $\begin{array}{l}.43 \\
.85\end{array}$ & $\begin{array}{r}8.0 \\
35.2\end{array}$ & $\begin{array}{l}1.53 \\
2.53\end{array}$ \\
\hline Hemicellulose & HEMI & 25.5 & .73 & 24.6 & .41 & 25.5 & .21 & 23.4 & .66 & 24.7 & 1.03 \\
\hline Silica & SIL & 7.4 & .18 & 7.3 & .16 & 6.4 & .19 & 4.8 & .49 & 6.4 & 1.12 \\
\hline \multicolumn{12}{|l|}{ Other Analyses } \\
\hline Gross energy $(\mathrm{Kcal} / \mathrm{gm})$ & GE & 4.16 & .09 & 3.85 & .03 & 3.75 & .01 & 3.81 & .01 & 3.88 & .15 \\
\hline Calcium $^{3}(\%)$ & $\mathrm{Ca}$ & .56 & $\mathrm{NA}$ & .46 & NA & .47 & NA & .55 & NA & .51 & .04 \\
\hline Phosphorus $^{3}(\%)$ & $\mathbf{P}$ & .07 & NA & .06 & NA & .08 & NA & .13 & NA & .09 & .03 \\
\hline Nitrates $^{3}(\mathrm{ppm})$ & NIT & 375.14 & NA & 375.20 & NA & 370.96 & NA & 370.82 & NA & 373.03 & 2.14 \\
\hline $\operatorname{Density}^{3}(\mathrm{~g} / \mathrm{cc})$ & DEN & .10 & NA & .09 & NA & .08 & NA & .08 & NA & .09 & .01 \\
\hline
\end{tabular}

'All values on a dry matter basis, $n=4$ samples of these hays for most analyses.

$z^{n}=3$ samples of this day for most analyses.

${ }^{3} n=1$ sample of each hay was analyzed

with $r^{2}=.43$.

It was also of interest to predict the actual DE of this forage. An all possible subsets regression was used to regress $D E$ on the same 13 practical laboratory variables. Six variables were found to be significant, resulting in the equation, $\mathrm{DE}=-83.499+854(\mathrm{DM})+$ .670 (CP) +. 100 (CF) - .497 (ASH) + .061 (IVDMD) + 82.840 (DEN) with $r^{2}=.93$. A slightly larger $r^{2}$ was obtained with a smaller number of independent variables than was obtained by Hertel (1976) for in vitro DE. Her equation, $D E=2.384+.043$ (IVDMD) -.049 (SIL) - .054 (CP) - .027 (CELL) -.005 (NDF) + .004 (DNDF) - .029 (LIG) - .009 (HEMI), had an $r^{2}$ of .90 .
Although the determination of TDN is often considered outdated, the measurement of TDN is of value for comparisons with older data on other forages. The results of an all possible subsets regression of TDN on the 13 variables resulted in the equation, $\mathrm{TDN}=-626.178+7.320(\mathrm{DM})+.562\left(\right.$ IVDMD) and an $r^{2}=.56$. The relatively low $r^{2}$ of this equation is consistent with other attempts to predict TDN values in forages (Butterworth and Diaz 1969).

Finally, an all possible subsets regression analysis was made to predict the DMD from the 13 variables. The resulting equation was $\mathrm{DMD}=-1167.600+12.430(\mathrm{DM})+1.556(\mathrm{CF})-4.791(\mathrm{ASH})+$

Table 2. Digestibility (\%) and feed intake of 4 cuttings of Kleberg bluestem hay.

\begin{tabular}{|c|c|c|c|c|c|c|c|c|c|c|c|}
\hline \multirow[b]{2}{*}{ Components ${ }^{2}$} & \multirow{2}{*}{$\begin{array}{c}\text { Text } \\
\text { abbreviations }\end{array}$} & \multicolumn{10}{|c|}{ Hays ${ }^{1}$} \\
\hline & & $A^{4}$ & S.D. & B & S.D. & C & S.D. & D & S.D. & $\bar{X}$ & S.D. \\
\hline Dry matter & DDM & 46.85 & 4.48 & 36.27 & 5.73 & 45.63 & 2.57 & 38.44 & 7.17 & 41.80 & 6.77 \\
\hline Protein & DP & 1.15 & .16 & .35 & .10 & .93 & .39 & .71 & .24 & .79 & .37 \\
\hline Ether extract & DEE & 1.94 & .26 & .96 & .16 & .35 & .17 & .60 & .37 & .96 & .63 \\
\hline Crude Fiber & $\mathrm{DF}$ & 10.40 & 1.19 & 9.40 & .98 & 14.35 & 2.06 & 9.75 & 2.69 & 10.98 & 2.79 \\
\hline Nitrogen free extract & DNFE & 38.48 & 3.91 & 34.82 & 4.97 & 36.01 & 2.22 & 35.10 & 3.41 & 36.10 & 3.85 \\
\hline Neutral detergent fiber & DNDF & 42.62 & 3.02 & 38.82 & 4.41 & 48.95 & 2.52 & 40.68 & 5.32 & 42.77 & 5.52 \\
\hline Cell contents & $\mathrm{DCC}$ & 14.92 & 2.04 & 8.15 & 1.04 & 7.18 & .28 & 8.75 & 2.18 & 9.75 & 3.23 \\
\hline Acid detergent fiber & DADF & 20.87 & 2.16 & 19.60 & 3.28 & 27.21 & 2.71 & 22.39 & 4.36 & 22.24 & 4.33 \\
\hline Cellulose & DCELL & 20.57 & .96 & 20.15 & 2.32 & 26.48 & 1.33 & 21.90 & 2.51 & 22.28 & 3.16 \\
\hline Hemicellulose & DHEMI & 21.74 & .92 & 19.23 & 1.56 & 21.74 & .29 & 18.43 & 1.20 & 20.28 & 1.83 \\
\hline \multicolumn{12}{|l|}{ In vitro dry matter } \\
\hline digestibility & IVDMD & 45.91 & NA & 33.37 & NA & 42.25 & NA & 40.59 & NA & 40.53 & 4.48 \\
\hline Energy (Mcal DE/kg) & DE & 2.64 & .14 & 1.90 & .21 & 2.16 & .15 & 1.86 & .39 & 2.14 & .38 \\
\hline Total digesta ble nutrients & TDN & 54.40 & 5.24 & 46.72 & 5.43 & 52.34 & 1.83 & 45.13 & 5.22 & 49.65 & 5.54 \\
\hline \multicolumn{12}{|l|}{ Feed Intake ${ }^{3}$} \\
\hline $\mathrm{Kg} / \mathrm{hd} /$ day & DMI/hd & 4.36 & .75 & 3.74 & .61 & 3.82 & .83 & 3.47 & .65 & 3.82 & .76 \\
\hline $\mathrm{Kg} / \mathrm{bw}$ & $\mathrm{DMI} / \mathbf{k g}$ & .002 & .004 & .018 & .003 & .018 & .004 & .017 & .003 & .018 & .004 \\
\hline $\mathbf{K G} / \mathbf{b w}^{75}$ & DMl $/ \mathbf{k g}^{75}$ & .081 & .014 & .068 & .009 & .069 & .016 & .016 & .011 & .070 & .013 \\
\hline
\end{tabular}

'All values are on a dry matter basis

${ }^{2} n=4$ steers for each hay for digestibility determinations

${ }^{3} \mathrm{n}=16$ steers for most hays for intake measurements

${ }^{4} n=12$ steers for this hay for intake measurement 
1.286 (IVDMD) +737.273 (DEN) with $r^{2}=82$. This equation may be more useful than that of Rama Raoet al. (1972), whose equation for in vitro $\mathrm{DMD}=-77.56+1.711(\mathrm{CP})+4.7(\mathrm{ADF})-.05\left(\mathrm{ADF}^{2}\right)$ with an $r^{2}=.87$, of that of Paquay et al. (1971), whose equation for the prediction of in vivo DMD, DMD $=89.58-.557$ (DE) - 863 (CF) had an $r^{2}$ of .67 and required of the determination of actual digestible energy.

In conclusion, the low $r^{2}$ for both equations predicting DMI/ $\mathrm{bw}_{\mathrm{kg}}^{75}$ indicate that the dry matter intake of this forage cannot be practically predicted from either routine or extensive laboratory analyses currently in use. The relatively high $r^{2}$ for the equations predicting DE and DMD indicate that these parameters can be estimated from analyses commonly done in forage testing laboratories. One must be cautious about applying these prediction equations to other forages or even higher quality samples of Kleberg bluestem. In an area where this forage is abundant and if universally low quality, however, such equations may be useful.

\section{Literature Cited}

AOAC. 1980. Official Methods Analysis. (12th Ed.) Association of Official Analytical Chemists, Washington, D.C.
Bremner, J.M. 1965. Methods of Soil Analysis, Part 2. Amer. Soc. of Agronomy, Inc. Madison, Wis.

Butterworth, M.H., and P. Butterworth. 1965. Some aspects of the utilization of tropical forages. II. Pangola and coastal Bermuda hays. J. Agr. Sci. 20:389.

Goering, H.K., and P.J. Van Soest. 1970. Forage Fiber Analysis, Agr. Handbook No. 379. USDA-ARS, Beltsville, Md.

Hertel, J.M. 1976. Digestible energy determination by use of in vitro residue through bomb calorimentry on Kleberg bluestem (Dicanthium annulatum (Forsk.) Staph.) M.S. Thesis, Texas A\&I Univ. Kingsville.

Moore, J.E., and D.G. Dunham. 1971. Procedure for the two stage in vitro digestion of forages. Univ. Florida, Gainesville. (Mimeo).

Moore, J.E., and G.O. Mott. 1973. Structural inhibitors of quality in tropical grasses. In: A.G. Marches (Ed) Antiquality Components of Forages. CSSA Spec. Pub. No. 4, Crop Sci. Soc. Amer., Madison, Wis.

Paquay, R., R. De Baere, and A. Lousse. 1971. Statistical research on digestibility in the cow. I. Dry matter and energy. J. Agr. Sci. 78:135.

Pennsylvania State University. 1978. Evaluation of the plywood box for measuring feed density. Pennsylvania State Univ., University Park, Pa. (Mimeo).

Rama Rao, M., H. Harbors, and E.F. Smith. 1972. Seasonal change in nutritive value of bluestem pastures. J. Range Manage. 26:419.

Schneider, B.H., and W.P. Flatt. 1975. The evaluation of feeds through digestibility experiments. University of Georgia Press, Athens, Ga.

\section{Membership in the Society for Range Management. . .}

is apen to those engaged in or interested in the study. management, or use of range ecosystems and the intelligent use of all range resources

includes research scientists, ronchers, governmental coency administrators and tectnical personnel. teachers, students, and people from the business community

provides members with two publications-one oriented to research (Joumal of Range Management) and the other oriented to proctical resource manoogment (Rangelands) offers apportunities for face-to-foce exchange of ideas at local. national, and international meetings of the Society.

Dues vary according to type of membership and geographical section. For application forms and additional information, contact the:

Execulive Secretory

Society tor Range Mangoement

2760 West Fitth Avenue

Denver, Colorodo 80204

(303) $571-0174$

\begin{tabular}{|c|c|c|c|c|c|c|c|}
\hline \multirow[b]{2}{*}{ DUES SCHEDULE } & \multirow[b]{2}{*}{ Regular } & \multirow[b]{2}{*}{ Student } & \multirow[b]{2}{*}{ Sustaining } & \multirow[b]{2}{*}{ Emeritus } & \multirow[b]{2}{*}{ Institutional } & \multicolumn{2}{|c|}{ Family } \\
\hline & & & & & & $\begin{array}{l}\text { First } \\
\text { Member }\end{array}$ & $\begin{array}{c}\text { Each } \\
\text { Additional }\end{array}$ \\
\hline ARIZONA & $\$ 43.00$ & $\$ 22.00$ & 564.00 & s 30.00 & $\$ 203.00$ & 543.00 . & $\ldots 23.00$ \\
\hline CALIFORNIA $\ldots .$. & 45.00 & 23.00 & 68.00 & 30.00 & 225.00 & 45.00 & .23 .00 \\
\hline COLORADO $\ldots \ldots \ldots \ldots \ldots \ldots$ & 42.00 & 22.00 & 62.00 & 29.00 & 202.00 & 42.00 & .2200 \\
\hline IDAHO $\ldots \ldots \ldots \ldots \ldots \ldots \ldots$ & 42.00 & 22.00 & 62.00 & 29.00 & 202.00 & 42.00 & $\ldots 22.00$ \\
\hline KANSAS-OKLAHOMA ....... & 43.00 & 22.00 & 62.00 & 29.00 & 203.00 & 43.00 & $\ldots 23.00$ \\
\hline MEXICO $\ldots \ldots \ldots \ldots \ldots \ldots$ & 44.00 & 24.00 & 64.00 & 31.00 & 204.00 & 44.00 & $\ldots 24.00$ \\
\hline NEBRASKA $\ldots \ldots \ldots \ldots \ldots$ & 44.00 & 22.00 & 64.00 & 31.00 & 204.00 & 44.00 & .24 .00 \\
\hline NEVADA $\ldots \ldots \ldots \ldots \ldots \ldots \ldots$ & 42.00 & 22.00 & 62.00 & 29.00 & 202.00 & 42.00 & .22 .00 \\
\hline NEW MEXICO .............. & 42.00 & 21.00 & 62.00 & 29.00 & 202.00 & 42.00 & 22.00 \\
\hline NORTHERN GREAT PLAINS. & 43.00 & 23.00 & 63.00 & 30.00 & 203.00 & 43.00 . & 23.00 \\
\hline INTERNATIONAL MNTN .... & 43.00 & 23.00 & 63.00 & 30.00 & 203.00 & 43.00 . & 23.00 \\
\hline PACIFIC NORTHWEST ...... & 45.00 & 25.00 & 65.00 & 32.00 & 205.00 & 45.00 & 25.00 \\
\hline SOUTH DAKOTA,$\ldots \ldots \ldots \ldots$ & 44.00 & 23.00 & 63.00 & 30.00 & 204.00 & 44.00 . & 24.00 \\
\hline SOUTHERN $\ldots \ldots \ldots \ldots \ldots$ & 45.00 & 25.00 & 65.00 & 32.00 & 205.00 & 45.00 & 25.00 \\
\hline FLORIDA $\ldots \ldots \ldots$ & 45.00 & 25.00 & 65.00 & 32.00 & 205.00 & 45.00 . & 25.00 \\
\hline TEXAS $\ldots \ldots \ldots \ldots \ldots \ldots \ldots$ & 43.00 & 21.50 & 63.00 & 30.00 & 203.00 & 43.00 & 23.00 \\
\hline UTAH $\ldots \ldots \ldots \ldots \ldots \ldots \ldots \ldots$ & 43.00 & 23.00 & 63.00 & 30.00 & 203.00 & 43.00 & 23.00 \\
\hline WYOMING & 43.00 & 22.00 & 63.00 & 30.00 & 203.00 & 43.00 & 23.00 \\
\hline NATIONAL CAPITAL ........ & 42.00 & 22.00 & 62.00 & 29.00 & 202.00 & 42.00 & 22.00 \\
\hline NORTH CENTRAL $\ldots \ldots \ldots$ & 42.00 & 22.00 & 62.00 & 29.00 & 202.00 & 42.00 & $\ldots 22.00$ \\
\hline UNSECTIONED & 40.00 & 20.00 & 60.00 & 27.00 & 200.00 & 40.00 & 20.00 \\
\hline
\end{tabular}

